Jurnal Mahasiswa BK An-Nur : Berbeda, Bermakna, Mulia

Volume 7 Nomor 3 Tahun 2021

Tersedia Online: https://ojs.uniska-bjm.ac.id/index.php/AN-NUR

p-ISSN. 2460-9722 | e-ISSN. 2622-8297

\title{
LAYANAN INFORMASI TENTANG TAHAPAN PERKEMBANGAN PSIKOSOSIAL PADA GURU TK BALITA QUR'AN JAKARTA
}

\author{
Devi Ratnasari ${ }^{1}$, Christine Masada ${ }^{2}$ \\ ${ }^{1}$ Universitas Indraprasta PGRI \\ ${ }^{2}$ Universitas Indraprasta PGRI \\ E-mail:ratnasaridevi37@yahoo.com/081387908484
}

\begin{abstract}
ABSTRAK
Abstrak Penelitian ini bertujuan untuk mengetahui gambaran proses kegiatan layanan informasi dan respon peserta kegiatan layanan informasi tentang tahapan perkembangan psikososial. Penelitian ini menggunakan metode kualitatif dengan jenis deskriptif kualitatif. Sumber data merupakan kelompok guru TK Balita Qur'an yang berjumlah 10 orang. Berdasarkan data hasil penelitian yang telah dilakukan, maka dapat disimpulkan bahwa proses kegiatan layanan informasi tentang tahapan perkembangan psikososial pada guru TK Balita Qur'an dapat berjalan dengan lancar. Rangkaian kegiatan dikemas dalam tahapan POAC, yaitu planning, organizing, actuating. controlling. Respon yang ditunjukkan peserta juga sangat baik dengan adanya keaktifan peserta dalam bertanya juga ketertiban peserta dalam menyimak kegiatan layanan informasi. Rsepon peserta tersebut diperlihatkan pula dalam aspek berpikir, merasa, bersikap, bertindak, dan bertanggungjawab (BMB3).
\end{abstract}

Kata Kunci: Layanan Informasi;Perkembangan Psikososial

\begin{abstract}
This study aims to describe the process of information service activities and the responses of participants in information service activities about the stages of psychosocial development. This study uses a qualitative method with a qualitative descriptive type. The data source is a group of 10 Balita Qur'an Kindergarten teachers. Based on the data from the research that has been carried out, it can be concluded that the process of information service activities about the stages of psychosocial development in Balita Qur'an Kindergarten teachers can run smoothly. The series of activities are packaged in POAC stages, namely planning, organizing, actuating. controlling. The response shown by the participants was also very good with the active participation of participants in asking questions and the orderliness of participants in listening to information service activities. The participants' responses were also shown in the aspects of thinking, feeling, behaving, acting, and being responsible (BMB3).
\end{abstract}

Keywords: : Information Service, Psychosocial Development

Dipublikasikan Oleh :

UPT Publikasi dan Pengelolaan Jurnal

Universitas Islam Kalimantan Muhammad Arsyad Al-Banjari Banjarmasin 


\section{Devi Ratnasari ${ }^{1}$, Christine Masada ${ }^{2}$ \\ Jurnal Mahasiswa BK An-Nur : Berbeda, Bermakna, Mulia \\ Volume 7 Nomor 3 Tahun 2021 \\ Tersedia Online: https://ojs.uniska-bjm.ac.id/index.php/AN-NUR \\ p-ISSN. 2460-9722 | e-ISSN. 2622-8297}

\section{PENDAHULUAN}

Tahapan psikososial merupakan tahapan penting bagi kehidupan manusia. Teori perkembangan psikososial (Muri'ah \& Wardan, 2020) berhubungan dengan kaidah prinsip perkembangan psikologi dan sosial. Teori tersebut juga merupakan bentuk pengembangan lebih lanjut dari teori psikoseksual yang dibuat oleh Sigmund Freud. Melalui bukunya "Childhood and Society", Erikson membuat sebuah susunan bagan untuk menuliskan delapan tahap secara terpisah tentang perkembangan ego dalam psikososial, yang biasa dikenal dengan sebutan "Delapan Tahap Perkembangan Manusia".

Delapan tahapan perkembangan manusia pada teori psikososial meliputi; 1) trust vs mistrust (percaya vs tidak percaya) pada usia kelahiran - 18 bulan, 2) autonomy vs doubt (kemandirian vs keraguan) pada usia 18 bulan -3 tahun, 3) initiative vs guilt (inisiatif vs rasa bersalah) pada usia 3 tahun -6 tahun, 4) industry vs inferiority (ketekunan vs rendah diri) pada usia 6 tahun - 12 tahun, 5) identity vs role (identitas vs kekacauan) pada usia 12 - 18 tahun, 6) intimacy vs isolation (keintiman vs isolasi) pada usia 18 tahun sampai 40 rahun, 7) generativity vs self absorption (generativitas vs stagnansi) pada usia 40 tahun sampai 65 tahun, 8) integrity vs despair (integritas vs keputusasaan) pada usia 65 tahun keatas (Muharrahman, 2019). Pada penelitian ini, yang menjadi sasaran penelitian adalah guru TK Balita Qur'an yang mengajar anak usia 3 tahun sampai 6 tahun. Jika dikaitkan dengan tahapan perkembangan psikososial, maka para siswa yang diajar oleh para guru TK tersebut berada pada tahap perkembangan nomor 3 yaitu inisiatif vs rasa bersalah. Maka, pemahaman tentang tahap perkembangan tersebut harus dimiliki oleh para guru TK di sekolah tersebut agar mampu memberikan stimulus dan respon yang tepat pada siswa sesuai tahapan perkembangannya. Perlakuan yang kurang tepat pada tahapan perkembangan tersebut tentu dapat memunculkan beberapa dampak negatif.

Salah satu dampak negatif yang dapat dimunculkan apabila anak mengalami stimulasi yang kurang tepat yaitu berkurangnya atau minimnya rasa inisiatif, misalnya pada tahap perkembangan yang ketiga yaitu initiative vs guilt (inisiatif vs rasa bersalah) pada usia 3 tahun -6 tahun,. Perasaan yang dominan berkembang justru pada "rasa bersalah". Misalnya, pada anak usia 3-6 tahun, yang sering mendapatkan larangan ketika bermain dan mengeksplor lingkungannya, maka anak akan cenderung selalu merasa bersalah dalam melakukan hal baru. Perasaan tersebut dapat terbawa sampai anak tersebut menginjak usia dewasa. Anak akan selalu dihadapkan pada "perasaan bersalah" tatkala ia berusaha mengembangkan idenya akan sesuatu hal, karena ia terbiasa dilarang untuk mengembangkan idenya. Begitu juga dengan anak yang selalu dibiarkan inisiatifnya berkembang tanpa diberikan arahan atau kendali diri, maka anak nantinya akan memiliki rasa inisiatif berlebihan. Akibatnya anak akan menjadi pribadi kurang peduli dan kurang dapat mengnedalikan dirinya. Pernyataan tersebut sesuai dengan pendapat (Mutmainnah, 2019) yang mengemukakan bahwa sesuatu yang terlalu berlebihan atau justru sebaliknya (kekurangan) merupakan hal yang tidak baik. Bila individu memiliki sikap inisiatif berlebihan atau juga terlalu kurang, maka dapat menimbulkan suatu rasa ketidakpedulian atau "cuek" (ruthlessness). Anak yang memiliki rasa inisiatif berlebihan, juga akan kurang mempedulikan bimbingan orangtua yang ditujukan kepada dirinya. Begitu juga sebaliknya, anak yang memiliki rasa bersalah berlebihan, akan cenderung menghindari inisiatif untuk melakukan sesuatu karena ingin terhindar dari kesalahan. Jadi, diperlukan stimulus yang tepat dari orangtua dan guru agar tahapan psikososial pada anak dapat berkembang optimal.

Terdapat beberapa penelitian terkait pentingnya stimulus pada anak yang dilakukan oleh orangtua maupun guru, khususnya di tahap perkembangan psikososial. (Hasneli, n.d.) melakukan penelitian pada 75 orangtua yang berada di RW 11 Kelurahan Tuah Karya Kecamatan Tampan Pekanbaru dengan menggunakan teknik purposive sampling. Hasil penelitian menunjukkan bahwa terdapat hubungan antara peran orangtua dengan perkembangan psikososial anak usia sekolah dengan signifikansi 0,05 diperoleh $\mathrm{p}$ value $<0,05$ yaitu 0,000 . Selanjutnya, penelitian oleh (Hastuti, 2009) yang melakukan penelitian untuk mengidentifikasi stimulasi psikososial yang diberikan pada kelompok bermain (KB) terpilih di Bogor dan pengaruhnya terhadap motorik, kognitif, sosio-emosional, dan perkembangan moral anak. Hasil penelitian menunjukkan bahwa adanya stimulasi di rumah dari orangtua serta stimulasi di sekolah termasuk optimalisasi fasilitas bermain dapat meningkatkan skor dalam hal motorik, kognitif, sosio-emosional dan perkembangan moral anak.

Maka, dalam penelitian ini nantinya peneliti akan memberikan layanan informasi tentang tahapan perkembangan psikososial yang terjadi pada anak, agar para guru di TK Balita Qur'an dapat memberikan

Dipublikasikan Oleh :

UPT Publikasi dan Pengelolaan Jurnal

Universitas Islam Kalimantan Muhammad Arsyad Al-Banjari Banjarmasin 


\section{Devi Ratnasari ${ }^{1}$, Christine Masada ${ }^{2}$ \\ Jurnal Mahasiswa BK An-Nur : Berbeda, Bermakna, Mulia \\ Volume 7 Nomor 3 Tahun 2021 \\ Tersedia Online: https://ojs.uniska-bjm.ac.id/index.php/AN-NUR}

p-ISSN. 2460-9722 | e-ISSN. 2622-8297

stimulasi yang tepat sesuai tahapan perkembangan psikosial yang terjadi pada anak, khususnya usia 3-6 tahun. Selanjutnya, peneliti menganalisis pelaksanaan layanan informasi yang diberikan, untuk mengetahui tentang proses kegiatan yang dilakukan. Layanan informasi merupakan salah satu jenis layanan dalam bimbingan dan konseling.

Layanan informasi (Hidayati, 2015), merupakan salah satu jenis layanan dasar dalam bimbingan konseling yang sangat penting untuk membantu individu agar dapat terhindar dari berbagai masalah yang dapat mengganggu terhadap pencapaian perkembangannya, baik yang berhubungan dengan diri pribadi, sosial, belajar ataupun kariernya. Melalui layanan informasi diharapkan individu dapat menerima dan memahami berbagai informasi, yang dapat dipergunakan sebagai bahan pertimbangan dalam pengambilan keputusan untuk kepentingan dirinya. Prayitno (Aristiani, 2016) mengemukakan bahwa "layanan informasi berusaha memenuhi kekurangan individu akan informasi yang mereka perlukan. Dalam layanan ini, kepada peserta layanan disampaikan berbagai informasi. Informasi itu kemudian diolah dan digunakan oleh individu untuk kepentingan hidup dan perkembangannya".

Oleh karena itu, peneliti memilih layanan informasi untuk diberikan kepada para guru di TK Balita Qur'an karena ingin memberikan materi terkait tahapan perkembangan psikososial, yang meliputi karakteristik perkembangannya dan bagaimana cara menstimulasinya. Penelitian ini akan dibuat dengan metode kualitatif dengan jenis deskriptif kualitatif.

Berdasarkan pemaparan sebelumnya maka peneliti tertarik untuk melakukan penelitian mengenai "Analisis Layanan Informasi tentang Tahapan Perkembangan Psikososial Pada Guru TK Balita Qur'an ".

\section{METODE}

Tahapan psikososial merupakan tahapan penting bagi kehidupan manusia. Teori perkembangan psikososial (Muri'ah \& Wardan, 2020) berhubungan dengan kaidah prinsip perkembangan psikologi dan sosial. Teori tersebut juga merupakan bentuk pengembangan lebih lanjut dari teori psikoseksual yang dibuat oleh Sigmund Freud. Melalui bukunya "Childhood and Society", Erikson membuat sebuah susunan bagan untuk menuliskan delapan tahap secara terpisah tentang perkembangan ego dalam psikososial, yang biasa dikenal dengan sebutan "Delapan Tahap Perkembangan Manusia”.

Delapan tahapan perkembangan manusia pada teori psikososial meliputi; 1) trust vs mistrust (percaya vs tidak percaya) pada usia kelahiran - 18 bulan, 2) autonomy vs doubt (kemandirian vs keraguan) pada usia 18 bulan 3 tahun, 3) initiative vs guilt (inisiatif vs rasa bersalah) pada usia 3 tahun - 6 tahun, 4) industry $v s$ inferiority (ketekunan vs rendah diri) pada usia 6 tahun - 12 tahun, 5) identity vs role (identitas vs kekacauan) pada usia 12 - 18 tahun, 6) intimacy vs isolation (keintiman vs isolasi) pada usia 18 tahun sampai 40 rahun, 7) generativity vs self absorption (generativitas vs stagnansi) pada usia 40 tahun sampai 65 tahun, 8) integrity vs despair (integritas vs keputusasaan) pada usia 65 tahun keatas (Muharrahman, 2019). Pada penelitian ini, yang menjadi sasaran penelitian adalah guru TK Balita Qur'an yang mengajar anak usia 3 tahun sampai 6 tahun. Jika dikaitkan dengan tahapan perkembangan psikososial, maka para siswa yang diajar oleh para guru TK tersebut berada pada tahap perkembangan nomor 3 yaitu inisiatif vs rasa bersalah. Maka, pemahaman tentang tahap perkembangan tersebut harus dimiliki oleh para guru TK di sekolah tersebut agar mampu memberikan stimulus dan respon yang tepat pada siswa sesuai tahapan perkembangannya. Perlakuan yang kurang tepat pada tahapan perkembangan tersebut tentu dapat memunculkan beberapa dampak negatif.

Salah satu dampak negatif yang dapat dimunculkan apabila anak mengalami stimulasi yang kurang tepat yaitu berkurangnya atau minimnya rasa inisiatif, misalnya pada tahap perkembangan yang ketiga yaitu initiative vs guilt (inisiatif vs rasa bersalah) pada usia 3 tahun - 6 tahun,. Perasaan yang dominan berkembang justru pada "rasa bersalah". Misalnya, pada anak usia 3-6 tahun, yang sering mendapatkan larangan ketika bermain dan mengeksplor lingkungannya, maka anak akan cenderung selalu merasa bersalah dalam melakukan hal baru. Perasaan tersebut dapat terbawa sampai

Dipublikasikan Oleh :

UPT Publikasi dan Pengelolaan Jurnal

Universitas Islam Kalimantan Muhammad Arsyad Al-Banjari Banjarmasin 


\section{Devi Ratnasari ${ }^{1}$, Christine Masada ${ }^{2}$ \\ Jurnal Mahasiswa BK An-Nur : Berbeda, Bermakna, Mulia \\ Volume 7 Nomor 3 Tahun 2021 \\ Tersedia Online: https://ojs.uniska-bjm.ac.id/index.php/AN-NUR}

p-ISSN. 2460-9722 | e-ISSN. 2622-8297

anak tersebut menginjak usia dewasa. Anak akan selalu dihadapkan pada "perasaan bersalah" tatkala ia berusaha mengembangkan idenya akan sesuatu hal, karena ia terbiasa dilarang untuk mengembangkan idenya. Begitu juga dengan anak yang selalu dibiarkan inisiatifnya berkembang tanpa diberikan arahan atau kendali diri, maka anak nantinya akan memiliki rasa inisiatif berlebihan. Akibatnya anak akan menjadi pribadi kurang peduli dan kurang dapat mengnedalikan dirinya. Pernyataan tersebut sesuai dengan pendapat (Mutmainnah, 2019) yang mengemukakan bahwa sesuatu yang terlalu berlebihan atau justru sebaliknya (kekurangan) merupakan hal yang tidak baik. Bila individu memiliki sikap inisiatif berlebihan atau juga terlalu kurang, maka dapat menimbulkan suatu rasa ketidakpedulian atau "cuek" (ruthlessness). Anak yang memiliki rasa inisiatif berlebihan, juga akan kurang mempedulikan bimbingan orangtua yang ditujukan kepada dirinya. Begitu juga sebaliknya, anak yang memiliki rasa bersalah berlebihan, akan cenderung menghindari inisiatif untuk melakukan sesuatu karena ingin terhindar dari kesalahan. Jadi, diperlukan stimulus yang tepat dari orangtua dan guru agar tahapan psikososial pada anak dapat berkembang optimal.

Terdapat beberapa penelitian terkait pentingnya stimulus pada anak yang dilakukan oleh orangtua maupun guru, khususnya di tahap perkembangan psikososial. (Hasneli, n.d.) melakukan penelitian pada 75 orangtua yang berada di RW 11 Kelurahan Tuah Karya Kecamatan Tampan Pekanbaru dengan menggunakan teknik purposive sampling. Hasil penelitian menunjukkan bahwa terdapat hubungan antara peran orangtua dengan perkembangan psikososial anak usia sekolah dengan signifikansi 0,05 diperoleh $\mathrm{p}$ value $<0,05$ yaitu 0,000 . Selanjutnya, penelitian oleh (Hastuti, 2009) yang melakukan penelitian untuk mengidentifikasi stimulasi psikososial yang diberikan pada kelompok bermain (KB) terpilih di Bogor dan pengaruhnya terhadap motorik, kognitif, sosio-emosional, dan perkembangan moral anak. Hasil penelitian menunjukkan bahwa adanya stimulasi di rumah dari orangtua serta stimulasi di sekolah termasuk optimalisasi fasilitas bermain dapat meningkatkan skor dalam hal motorik, kognitif, sosio-emosional dan perkembangan moral anak.

Maka, dalam penelitian ini nantinya peneliti akan memberikan layanan informasi tentang tahapan perkembangan psikososial yang terjadi pada anak, agar para guru di TK Balita Qur'an dapat memberikan stimulasi yang tepat sesuai tahapan perkembangan psikosial yang terjadi pada anak, khususnya usia $3-6$ tahun. Selanjutnya, peneliti menganalisis pelaksanaan layanan informasi yang diberikan, untuk mengetahui tentang proses kegiatan yang dilakukan. Layanan informasi merupakan salah satu jenis layanan dalam bimbingan dan konseling.

Layanan informasi (Hidayati, 2015), merupakan salah satu jenis layanan dasar dalam bimbingan konseling yang sangat penting untuk membantu individu agar dapat terhindar dari berbagai masalah yang dapat mengganggu terhadap pencapaian perkembangannya, baik yang berhubungan dengan diri pribadi, sosial, belajar ataupun kariernya. Melalui layanan informasi diharapkan individu dapat menerima dan memahami berbagai informasi, yang dapat dipergunakan sebagai bahan pertimbangan dalam pengambilan keputusan untuk kepentingan dirinya. Prayitno (Aristiani, 2016) mengemukakan bahwa "layanan informasi berusaha memenuhi kekurangan individu akan informasi yang mereka perlukan. Dalam layanan ini, kepada peserta layanan disampaikan berbagai informasi. Informasi itu kemudian diolah dan digunakan oleh individu untuk kepentingan hidup dan perkembangannya".

Oleh karena itu, peneliti memilih layanan informasi untuk diberikan kepada para guru di TK Balita Qur'an karena ingin memberikan materi terkait tahapan perkembangan psikososial, yang meliputi karakteristik perkembangannya dan bagaimana cara menstimulasinya. Penelitian ini akan dibuat dengan metode kualitatif dengan jenis deskriptif kualitatif. 


\section{Devi Ratnasari ${ }^{1}$, Christine Masada ${ }^{2}$ \\ Jurnal Mahasiswa BK An-Nur : Berbeda, Bermakna, Mulia \\ Volume 7 Nomor 3 Tahun 2021 \\ Tersedia Online: https://ojs.uniska-bjm.ac.id/index.php/AN-NUR \\ p-ISSN. 2460-9722 | e-ISSN. 2622-8297}

Berdasarkan pemaparan sebelumnya maka peneliti tertarik untuk melakukan penelitian mengenai "Analisis Layanan Informasi tentang Tahapan Perkembangan Psikososial Pada Guru TK Balita Qur'an ”.

\section{METODE}

Desain penelitian ini menggunakan penelitian kualitatif, dengan metode penelitian kualitatif deskriptif. Menurut Sugiyono (Anggito \& Setiawan, 2018), bahwa metode deskriptif adalah suatu metode yang digunakan untuk menggambarkan atau menganalisis suatu hasil penelitian tetapi tidak digunakan untuk membuat kesimpulan secara generalisasi. Whitney (Mamangkey, Aling, \& Longdong, 2020), mengungkapkan bahwa metode deskriptif adalah pencarian fakta dengan interpretasi yang tepat. Penelitian deskriptif merupakan suatu penelitian yang ditujukan untuk menyelidiki keadaan, kondisi, atau hal-hal yang sudah disebutkan, yang hasilnya dipaparkan dalam bentuk laporan penelitian (Arikunto, 2010). Informan penelitian merupakan orang-orang yang dapat memberikan informasi yang mendukung penelitian. Informan penelitian adalah sesuatu baik orang, benda ataupun lembaga (organisasi), yang sifat keadaanya diteliti (Rukajat, 2018). Informan dalam penelitian ini adalah satu kelompok guru TK di Balita Qur'an (10 orang) yang menjadi peserta layanan infromasi tentang tahapan perkembangan psikososial. Adapun kategori dari para informan tersebut sebagai berikut: (1) Memiliki usia pada rentang $20-40$ tahun. (2) Tinggal di area Kota Jakarta Timur. (3) Memiliki pengalaman mengajar >1 tahun.

Teknik pengumpulan data digunakan untuk mengumpulkan data sesuai tata cara penelitian yang pada akhirnya diperoleh data yang dibutuhkan. (Sugiyono, n.d.) teknik pengumpulan data merupakan langkah yang paling strategis dalam penelitian, karena tujuan utama dari penelitian adalah mengumpulkan data. Teknik pengumpulan data dalam penelitian ini menggunakan teknik wawancara, observasi, dan dokumentasi. Analisis data merupakan proses pencarian dan penyusunan secara sistematis data yang diperoleh melalui wawancara, catatan lapangan, dan bahan-bahan lain, sehingga dapat mudah dipahami, dan temuannya dapat diinformasikan kepada orang lain. Dilakukan dengan mengorganisasikan data, menjabarkannya kedalam unit-unit, melakukan sintesa, menyusun kedalam pola, memilih dan membuat kesimpulan (Sugiyono, n.d.).

Analisis data yang digunakan dalam penelitian ini, menggunakan model analaisis menurut Miles \& Huberman (Sugiyono, n.d.) aktivitas dalam menganalisis data kualitatif yaitu antara lain: (1) Reduksi data, (2) Penyajian data, dan (3) Penarikan kesimpulan.

\section{HASIL DAN PEMBAHASAN}

\section{Gambaran Proses Kegiatan Layanan Informasi tentang Tahapan Perkembangan Psikososial pada Guru TK Balita Qur'an}

Proses kegiatan layanan informasi tentang tahapan perkembangan psikososial pada guru TK Balita Qur'an dilakukan pada bulan Oktober 2020. Kegiatan dilakukan dengan proses tatap muka, tentunya tetap dengan menggunakan protocol kesehatan, mengingat masih dalam masa pandemi COVID 19. Kegiatan dilakukan di TK Balita Qur'an yang berlokasi di Jln. Ujung Gedong, Kec. Pasar Rebo, Kota Jakarta Timur. Proses kegiatan layanan informasi terbagi dalam tahapan yang termuat dalam tabel berikut:

Tabel 1.

POAC dalam kegiatan layanan informasi

\begin{tabular}{|c|c|c|c|}
\hline No & Tahapan & Keterangan & Temuan \\
\hline 1 & $\begin{array}{l}\text { Planning } \\
\text { (Perencanaan) }\end{array}$ & $\begin{array}{l}\text { Peneliti membuat rencana } \\
\text { dengan tim terkait waktu, } \\
\text { materi, dan kesiapan terkait } \\
\text { kegiatan layanan informasi } \\
\text { yang dilakukan }\end{array}$ & $\begin{array}{l}\text { Perencanaan dibuat dalam waktu } \\
\text { yang cukup singkat, sehingga } \\
\text { sebagai bahan evaluasi untuk } \\
\text { kegiatan selanjutnya, waktu } \\
\text { perencanaan perlu dibuat dalam } \\
\text { waktu yang lebih lama. Selain itu, } \\
\text { dalam proses perencanaan juga } \\
\text { perlu direncanakan tentang media } \\
\text { yang digunakan sebagai } \\
\text { optimalisasi kegiatan layanan }\end{array}$ \\
\hline
\end{tabular}

Dipublikasikan Oleh :

UPT Publikasi dan Pengelolaan Jurnal

Universitas Islam Kalimantan Muhammad Arsyad Al-Banjari Banjarmasin 
Devi Ratnasari ${ }^{1}$, Christine Masada ${ }^{2}$

Jurnal Mahasiswa BK An-Nur : Berbeda, Bermakna, Mulia

Volume 7 Nomor 3 Tahun 2021

Tersedia Online: https://ojs.uniska-bjm.ac.id/index.php/AN-NUR

p-ISSN. 2460-9722 | e-ISSN. 2622-8297

\begin{tabular}{|c|c|c|c|}
\hline & & & $\begin{array}{l}\text { informasi yang diberikan, oleh } \\
\text { karena itu pada kegiatan } \\
\text { selanjutnya perencanaan media } \\
\text { yang menarik dan kreatif } \\
\text { diperlukan dalam menunjang } \\
\text { kesuksesan kegiatan layanan } \\
\text { informasi yang dilaksanakan. }\end{array}$ \\
\hline 2 & $\begin{array}{l}\text { Organizing } \\
\text { (Pengorganisasian) }\end{array}$ & $\begin{array}{l}\text { Peneliti mengomunikasikan } \\
\text { hasil perencanaan kepada } \\
\text { kepala sekolah, lalu } \\
\text { memastikan jadwal } \\
\text { pelaksanaan serta tempat yang } \\
\text { akan digunakan dalam kegiatan } \\
\text { layanan informasi }\end{array}$ & $\begin{array}{l}\text { Proses komunikasi tentang } \\
\text { rencana yang telah disusun } \\
\text { kepada kepala sekolah menjadi } \\
\text { poin penting bagi kelancaran } \\
\text { proses pengorganisasian. Oleh } \\
\text { karena itu, skill dalam } \\
\text { mengomunikasikan diperlukan } \\
\text { agar dapat mengorganisasikan } \\
\text { kegiatan layanan informasi } \\
\text { dengan baik. Peneliti merasa } \\
\text { sudah dapat mengomunikasikan } \\
\text { rencana yang telah dibuat dengan } \\
\text { cara yang baik dan tepat, sehingga } \\
\text { kepala sekolah merasa antusias } \\
\text { dengan kegiatan yang dilakukan } \\
\text { di sekolahnya. Terlebih lagi } \\
\text { materi tentant tahapan } \\
\text { perkembangan psikososial } \\
\text { memang menjadi materi yang } \\
\text { dibutuhkan oleh para guru di TK } \\
\text { Balita Qur'an. }\end{array}$ \\
\hline 3 & $\begin{array}{l}\text { Actuating } \\
\text { (Pelaksanaan) }\end{array}$ & $\begin{array}{l}\text { Peneliti melaksanakan kegiatan } \\
\text { layanan informasi tentang } \\
\text { tahapan perkembangan } \\
\text { psikososial pada guru TK } \\
\text { Balita Qur'an selama } 3 \text { jam }\end{array}$ & $\begin{array}{l}\text { Pelaksanaan kegiatan dilakukan di } \\
\text { siang hari yaitu pukul } 14.00 \\
\text { sampai waktu sore hari yaitu } \\
\text { pukul 17.00, maka diperlukan } \\
\text { strategi untuk membuat suasana } \\
\text { tetap dirasa "asyik" oleh peserta } \\
\text { kegiatan layanan informasi, maka } \\
\text { peneliti membuat ice breaking } \\
\text { dengan permainan seru "ubah } \\
\text { mindset", peserta yang melakukan } \\
\text { kesalahan akan diberikan } \\
\text { konsekuensi untuk unjuk } \\
\text { kebolehan di hadapan peserta } \\
\text { yang lain. Adanya ice breaking } \\
\text { tersebut cukup dapat } \\
\text { memeriahkan suasana dan } \\
\text { membuat peserta bersemangat. } \\
\text { Selain itu, adanya keaktifan para } \\
\text { peserta dalam bertanya juga } \\
\text { membuat kegiatan berjalan } \\
\text { dinamis dan "hidup". }\end{array}$ \\
\hline 4 & $\begin{array}{l}\text { Controlling } \\
\text { (Penilaian) }\end{array}$ & $\begin{array}{l}\text { Peneliti melakukan penilaian } \\
\text { dengan penilaian segera } \\
\text { (laiseg) dengan BMB3 yang }\end{array}$ & $\begin{array}{l}\text { Peneliti menanyakan kepada } \\
\text { peserta terkait penilaian mereka } \\
\text { tentang kegiatan yang telah }\end{array}$ \\
\hline
\end{tabular}

Dipublikasikan Oleh :

UPT Publikasi dan Pengelolaan Jurnal

Universitas Islam Kalimantan Muhammad Arsyad Al-Banjari Banjarmasin 
Devi Ratnasari ${ }^{1}$, Christine Masada ${ }^{2}$

Jurnal Mahasiswa BK An-Nur : Berbeda, Bermakna, Mulia

Volume 7 Nomor 3 Tahun 2021

Tersedia Online: https://ojs.uniska-bjm.ac.id/index.php/AN-NUR

p-ISSN. 2460-9722 | e-ISSN. 2622-8297

\begin{tabular}{|c|c|c|c|}
\hline & & diperoleh peserta & $\begin{array}{l}\text { dilakukan, namun penilaian yang } \\
\text { dilakukan hanya penilaian segera } \\
\text { (laiseg). Maka, untuk kegiatan } \\
\text { layanan informasi selanjutnya, } \\
\text { penilaian yang perlu dilakukan } \\
\text { adalah penilaian jangka pendek } \\
\text { (laijapen) dan juga penilaian } \\
\text { jangka panjang (laijapang) agar } \\
\text { mendapat gambaran yang lebih } \\
\text { menyeluruh terkait kegiatan } \\
\text { layanan informasi yang telah } \\
\text { dilakukan. }\end{array}$ \\
\hline 5 & Tindak Lanjut & $\begin{array}{l}\text { Peneliti membantu para guru } \\
\text { TK Balita Qur'an akan } \\
\text { membuat program edukasi } \\
\text { emosi berdasarkan hasil atau } \\
\text { materi yang didapat dari } \\
\text { kegiatan layanan informasi }\end{array}$ & $\begin{array}{l}\text { Tindak lanjut merupakan bagian } \\
\text { penting dalam kegiatan layanan } \\
\text { informasi yang telah dilakukan, } \\
\text { sebagai pewujudan manfaat dari } \\
\text { kegiatan yang dilakukan. Pihak } \\
\text { sekolah sangat antusias dan } \\
\text { kooperatif dalam menyusun } \\
\text { tindak lanjut kegiatan layanan } \\
\text { informasi tentang tahapan } \\
\text { perkembangan psikososial yang } \\
\text { telah dilakukan. Pihak sekolah } \\
\text { menginginkan adanya kegiatan } \\
\text { yang berkelanjutan dan } \\
\text { berkesinambungan sehingga dapat } \\
\text { memberikan kebermanfaatan } \\
\text { yang bermakna guna dalam } \\
\text { mengembangkan kepribadian } \\
\text { positif pada peserta didik. }\end{array}$ \\
\hline
\end{tabular}

Tabel 2.

Respon BMB3 dari peserta layanan informasi

\begin{tabular}{|c|c|c|c|}
\hline No & Aspek BMB3 & Respon yang muncul & Interpretasi \\
\hline 1 & Berpikir & $\begin{array}{l}\text { "saya berpikir bahwa } \\
\text { orangtua siswa juga } \\
\text { sebenarnya perlu tahu ya } \\
\text { tentang tahapan ini, agar } \\
\text { nantinya program di sekolah } \\
\text { bisa sinkron dengan kegiatan } \\
\text { di rumah antara sang anak } \\
\text { dan orangtua" }\end{array}$ & $\begin{array}{l}\text { Para guru TK Balita Qur'an } \\
\text { memiliki pemikiran bahwa } \\
\text { orangtua juga perlu diberikan } \\
\text { layanan informasi tentang tahapan } \\
\text { perkembangan psikososial agar } \\
\text { dapat menyinkronkan antara } \\
\text { tujuan kegiatan di sekolah dengan } \\
\text { tujuan kegiatan di rumah. }\end{array}$ \\
\hline 2 & Merasa & $\begin{array}{l}\text { "saya merasa agak } \\
\text { mempertanyakan masa lalu } \\
\text { saya, yang dulunya tidak } \\
\text { mendapat perlakuan yang } \\
\text { harusnya ideal di tahapan } \\
\text { perkembangan psikososial, } \\
\text { apakah saya masih bisa } \\
\text { merubah diri saya atau } \\
\text { mengurangi efek negatif dari } \\
\text { pola pengasuhan yang }\end{array}$ & $\begin{array}{l}\text { Para guru TK Balita Quran ingin } \\
\text { mendapat kepastian tentang dapat } \\
\text { atau tidaknya luka masa lalu saat } \\
\text { pengasuhan disembuhkan atau } \\
\text { dikurangi efek negatifnya, agar } \\
\text { tidak mempengaruh sikap sebagai } \\
\text { guru dan berpengaruh di masa } \\
\text { depan. }\end{array}$ \\
\hline
\end{tabular}

Dipublikasikan Oleh :

UPT Publikasi dan Pengelolaan Jurnal

Universitas Islam Kalimantan Muhammad Arsyad Al-Banjari Banjarmasin 


\section{Devi Ratnasari ${ }^{1}$, Christine Masada ${ }^{2}$ \\ Jurnal Mahasiswa BK An-Nur : Berbeda, Bermakna, Mulia \\ Volume 7 Nomor 3 Tahun 2021 \\ Tersedia Online: https://ojs.uniska-bjm.ac.id/index.php/AN-NUR \\ p-ISSN. 2460-9722 | e-ISSN. 2622-8297}

\begin{tabular}{|c|c|c|c|}
\hline & & $\begin{array}{l}\text { kurang optimal pada diri } \\
\text { saya saat saya masih kecil" }\end{array}$ & \\
\hline 3 & Bersikap & $\begin{array}{l}\text { "berarti nanti saya akan } \\
\text { bersikap lebih sabar dan } \\
\text { lebih memfasilitasi anak } \\
\text { agar inisiatif anak dapat } \\
\text { tumbuh dengan baik" }\end{array}$ & $\begin{array}{l}\text { Para guru TK Balita Qur'an } \\
\text { memilih sikap lebih sabar dan } \\
\text { telaten dalam menghadapi peserta } \\
\text { didik, agar dapat berkembang } \\
\text { optimal sesuai tahapan } \\
\text { perkembangan psikososial. }\end{array}$ \\
\hline 4 & Bertindak & $\begin{array}{l}\text { "sebelum fokus ke siswa, } \\
\text { saya akan mencoba } \\
\text { menyelesaikan luka masa } \\
\text { lalu di masa pengasuhan } \\
\text { saya dulu, sehingga ketika } \\
\text { menghadapi siswa, saya } \\
\text { akan lebih siap" }\end{array}$ & $\begin{array}{l}\text { Para guru TK Balita Qur'an } \\
\text { melakukan tindakan untuk } \\
\text { "berdamai dengan diri sendiri" } \\
\text { untuk menyelesaikan luka lama } \\
\text { dalam pengasuhan, sehingga } \\
\text { dapat lebih siap ketika } \\
\text { menghadapi peserta didik. }\end{array}$ \\
\hline 5 & Bertanggungjawab & $\begin{array}{l}\text { "saya berkomitmen } \\
\text { menerapkan ilmu dari materi } \\
\text { layanan informasi ini } \\
\text { tentang materi tahapan } \\
\text { perkembangan psikososial" }\end{array}$ & $\begin{array}{l}\text { Para guru TK Balita Qur'an } \\
\text { memiliki komitmen untuk terus } \\
\text { belajar dan menerapkan segala } \\
\text { ilmu yang didapat dari materi } \\
\text { kegiatan layanan informasi } \\
\text { tentang tahapan perkembangan } \\
\text { psikososial yang telah diperoleh. }\end{array}$ \\
\hline
\end{tabular}

\section{Gambaran Respon Peserta Layanan Informasi tentang Tahapan Perkembangan Psikososial}

Peserta kegiatan layanan informasi tentang tahapan perkembangan psikososial memberikan respon antusias dan sangat baik saat kegiatan berlangsung. Terlebih lagi, beberapa peserta sering memberikan pertanyaan kepada peneliti sebagai respon berpikir dan dinamika BMB3 (Berpkir, Merasa, Bersikap, Bertindak, Bertanggungjawab) dalam proses kegiatan. Rangkuman terkait respon BMB3 yang ditunjukkan oleh informan sebagai peserta kegiatan layanan informasi disajikan dalam tabel 2 diatas.

\section{Pembahasan}

Layanan informasi yang diberikan peneliti kepada guru TK Balita Qur'an telah berjalan dengan lancar dan mendapat respon yang sangat baik dari peserta. Pencapaian tersebut didapatkan karena isi materi layanan merupakan hal yang tepat dan dikemas dalam kegiatan yang berdinamika. Kondisi tersebut sesuai dengan pendapat (Prayitno, 2017) yang menyatakan bahwa:

Informasi yang menjadi isi layanan harus spesifik dan dikemas secara jelas serta dirinci sehingga dapat disajikan secara efektif dan dipahami dengan baik oleh para peserta layanan. Informasi yang dimaksud itu sesuai dengan kebutuhan aktual para peserta layanan sehingga tingkat kebermanfaatan layanan tinggi.

Selain itu, layanan informasi yang diberikan kepada para guru TK Balita Qur'an juga dapa berfungsi sebagai fungsi pemahaman. Fungsi pemahaman (Ahmad Susanto, 2018) yaitu fungsi bimbingan yang membantu klien agar memiliki pemahaman terhadap dirinya (potensinya) dan lingkungannya (pendidikan, pekerjaan, dan norma agama). Berdasarkan pemahaman ini, siswa diharapkan mampu mengembangkan potensi dirinya secara optimal, dan menyesuaikan dirinya dengan lingkungan secara dinamis dan konstruktif.

Fungsi pemahaman yang dimaksud yaitu bimbingan dan konseling yang akan menghasilkan pemahaman tentang sesuatu oleh pihak-pihak tertentu sesuai dengan keperluan pengembangan sasaran layanan. Pemahaman ini mencakup:

a. Pemahaman tentang diri siswa, terutama oleh siswa sendiri, orang tua, guru dan guru pembimbing.

b. Pemahaman tentang lingkungan siswa (termasuk di dalamnya lingkungan keluarga dan sekolah), terutama oleh siswa sendiri, orang tua, guru, dan guru pembimbing.

c. Pemahaman tentang lingkungan yang lebih luas (termasuk di dalamnya informasi pendidikan,

Dipublikasikan Oleh :

UPT Publikasi dan Pengelolaan Jurnal

Universitas Islam Kalimantan Muhammad Arsyad Al-Banjari Banjarmasin 


\section{Devi Ratnasari ${ }^{1}$, Christine Masada ${ }^{2}$ \\ Jurnal Mahasiswa BK An-Nur : Berbeda, Bermakna, Mulia \\ Volume 7 Nomor 3 Tahun 2021 \\ Tersedia Online: https://ojs.uniska-bjm.ac.id/index.php/AN-NUR \\ p-ISSN. 2460-9722 | e-ISSN. 2622-8297}

jabatan, pekerjaan, dan atau karir, dan informasi budaya/nilai-nilai), terutama oleh sekolah.

Fokus utama pelayanan bimbingan dan konseling (Luddin, 2010), yaitu klien dengan berbagai permasalahannya, dan dengan tujuan-tujuan konseling. Berkenaan dengan kedua hal tersebut, pemahaman yang sangat perlu diwujudkan oleh pelayanan bimbingan dan konseling adalah pemahaman tentang diri klien beserta permasalahannya oleh klien sendiri, dan oleh pihakpihak yang akan membantu klien, serta pemahaman tentang lingkungan klien oleh klien.

Pemahaman masalah oleh individu sendiri merupakan modal dasar bagi pemecahan masalah tersebut, apabila pemahaman masalah telah tercapai,

\section{PENUTUP}

Berdasarkan data hasil penelitian yang telah dilakukan, maka dapat disimpulkan bahwa proses kegiatan layanan informasi tentang tahapan perkembangan psikososial pada guru TK Balita Qur'an dapat berjalan dengan lancar. Rangkaian kegiatan dikemas dalam tahapan POAC, yaitu planning, organizing, actuating. controlling. Respon yang ditunjukkan peserta juga sangat baik dengan adanya keaktifan peserta dalam bertanya juga ketertiban peserta dalam menyimak kegiatan layanan informasi. Rsepon peserta tersebut diperlihatkan pula dalam aspek berpikir, merasa, bersikap, bertindak, dan bertanggungjawab (BMB3).

\section{REFERENSI}

Al Fatha, P. R. (2020). Efektivitas Layanan Informasi Untuk Meningkatkan Komunikasi Antar Pribadi Pada Siswa Kelas X Man 1 Aceh Tenggara. AlMursyid: Jurnal Ikatan Alumni Bimbingan Dan Konseling Islam (IKABKI), 2(1).

Anggito, A., \& Setiawan, J. (2018). Metodologi penelitian kualitatif. CV Jejak (Jejak Publisher).

Arifyanto, A. T. (2020). Layanan Informasi Teknik Modeling Untuk Meningkatkan Motivasi Mahasiswadalam Penyelesaikan Tugas Akhir. Gema Pendidikan, 27(1), 62-74.

Arikunto, S. (2010). Metode Peneltian. Jakarta: Rineka Cipta.

Aristiani, R. (2016). Meningkatkan percaya diri siswa melalui layanan informasi berbantuan audiovisual. Jurnal Konseling Gusjigang, 2(2).

Emiliza, T. (2019). Konsep Psikososial Menurut Teori erik h. Erikson Terhadap Pendidikan Anak Usia agaknya pelayanan bimbingan dan konseling telah menjalankan fungsi pemahaman dengan baik. Pemahaman masalah siswa sama bergunanya dengan pemahaman tentang individu pada umumnya oleh orang tua dan guru sebagaimana telah dijelaskan di atas, yaitu untuk kepentingan berkenaan dengan perhatian dan pelayanan orang tua terhadap anak, dan pengajaran oleh guru terhadap siswa. Para siswa perlu memahami dengan baik lingkungan sekolah, dan juga perlu diberi kesempatan untuk memahami berbagai informasi yang berguna berkenaan dengan pendidikan yang sekarang dijalaninya dengan pendidikan jenjang selanjutnya dan yang berhubungan dengan pekerjaannya di kemudian hari.

Dini Dalam Tinjauan Pendidikan Islam Konsep Psikososial Menurut Teori Erik H. Erikson Terhadap Pendidikan Anak Usia Dini Dalam Tinjauan Pendidikan Islam. Iain Bengkulu.

Gunarsa, S. (2008). Psikologi perkembangan anak dan remaja. Retrieved from https://books.google.com/books?hl=en\&lr=\&id $=\mathrm{SDcYbzE}-$

dXAC\&oi=fnd\&pg=PA3\&dq=Berkaitan + denga $\mathrm{n}+$ pemeliharaan+kesehatan+mental,+mengungk apkan+bahwa+untuk+memelihara+kesehatan+ mental+dan+penyesuaian+yang+baik,+perilaku +manusia+harus+sesuai+dengan+sifat+manusia +sebagai+pribadi+yang+bermoral,+intelektual, + religius, +emosional+dan+sosial. + \&ots $=38 \mathrm{tTU}$ OgsbZ\&sig=94Kw0A2oAkPXJj2kohe1bsyxs8 Q

Hasneli, Y. (n.d.). Hubungan Peran Orang Tua Terhadap Perkembangan Psikososial Anak Usia Sekolah. Riau University.

Hastuti, D. (2009). Stimulasi psikososial pada anak kelompok bermain dan pengaruhnya pada perkembangan motorik, kognitif, sosial emosi, dan moral/karakter anak. Jurnal Ilmu Keluarga \& Konsumen, 2(1), 41-56.

Hendarto, B. D., \& Hartini, S. (2019). Pengaruh Layanan Informasi Dengan Media Film Terhadap Kemampuan Perencanaan Karir Pada Siswa Xi Ipa 4 Sma Negeri Colomadu Tahun Pelajaran 2015/2016. Medikons: Jurnal Prodi Bimbingan Dan Konseling Unisri Surakarta, 4(1).

Hidayati, R. (2015). Layanan Informasi karir membantu peserta didik dalam meningkatkan pemahaman karir. Jurnal Konseling GUSJIGANG, l(1), 107128.

Lestari, I. (2015). Pengembangan Layanan Informasi

Dipublikasikan Oleh :

UPT Publikasi dan Pengelolaan Jurnal

Universitas Islam Kalimantan Muhammad Arsyad Al-Banjari Banjarmasin 
Teknik Symbolic Model Dalam Membantu Mengembangkan Kemandirian Belajaranak Usia Sekolah Dasar. Jurnal Konseling GUSJIGANG, 1(1).

M Arie Praja S, M. (2011). Peranan Pendidikan Agama Islam Dalam Pembentukan Akhlak Siswa Di Mi Assafi'iyah Pikatan Wonodadi Blitar Tahun 2010/2011.

Mamangkey, R., Aling, D. R. R., \& Longdong, F. V. (2020). Dinamika Kelompok Daerah Perlindungan Laut Di Desa Bahoi Kecamatan Likupang Barat Kabupaten Minahasa Utara Provinsi Sulawesi Utara. Akulturasi: Jurnal Ilmiah Agrobisnis Perikanan, 8(2), 218-228.

Moleong, L. J. (2007). Metode penelitian kualitatif. Bandung: Remaja Rosdakarya.

Muharrahman, M. (2019). Perkembangan Anak Pada Masa Anak-Anak Awal Perspektif Erik Erikson. Jurnal I'TIBAR, 3(02).

Muri'ah, D. R. H. S., \& Wardan, K. (2020). Psikologi Perkembangan Anak dan Remaja. Literasi Nusantara.

Mutmainnah, M. (2019). Lingkungan Dan Perkembangan Anak Usia Dini Dilihat Dari Perspektif Psikologi. Gender Equality: International Journal of Child and Gender Studies, 5(2), 15-32.

Nurhayati, T. (2016). Perkembangan perilaku psikososial pada masa pubertas. Edueksos: Jurnal Pendidikan Sosial \& Ekonomi, 4(1).

Reindravi, S. (2000). Perkembangan Psikososial Anak. Bagian/SMF Psikiatri Fakultas Kedokteran Universitas Udayana/Rumah Sakit Umum Pusat Sanglah Denpasar.

Rukajat, A. (2018). Pendekatan Penelitian Kualitatif (Qualitative Research Approach). Deepublish.

Sari, E. W., Yusmansyah, Y., \& Dahlan, S. (2013). Penggunaan Layanan Informasi Dalam Bimbingan Dan Konseling Untuk Meningkatkan Aktivitas belajar. Alibkin (Jurnal Bimbingan Konseling), 2(4).

Sugiyono, P. (n.d.). Dr. 2010. Metode Penelitian Kuantitatif, Kualitatif, Dan R\&D. Bandung: $C V$ Alfabeta.

Utami, R. B. (2008). Pengaruh tingkat pendidikan dan tipe pola asuh orang tua terhadap perkembangan psikososial anak prasekolah di Taman Kanak-kanak Aisyiyah II Nganjuk. UNS (Sebelas Maret University).

Wulandari, W. (2017). Pencegahan Penyalahgunaan Narkoba Dengan Layanan Informasi Oleh Guru
Bimbingan Dan Konseling Di Smpn 3 BanjarbarU. Jurnal Mahasiswa BK An-Nur: Berbeda, Bermakna, Mulia, 3(2), 25-31.

\section{Dipublikasikan Oleh :}

UPT Publikasi dan Pengelolaan Jurnal 